\title{
Peran Pembiayaan Baitul Maal Wat Tamwil Terhadap Perkembangan Usaha dan Peningkatan Kesejahteraan Anggotanya dari Sektor Mikro Pedagang Pasar Tradisional
}

\author{
Fitriani Prastiawati \& Emile Satia Darma* \\ Prodi Akuntansi Universitas Muhammadiyah Yogyakarta, Jln. Lingkar Selatan, Kasihan, Bantul, D. I. Yogyakarta
}

\begin{tabular}{l} 
A R T I C L E I N F O \\
\hline Article history: \\
received 11 Mar 2016 \\
revised 13 Jun 2016 \\
accepted 17 Jun 2016
\end{tabular}

Keywords:

Baitul Maal Wat

Tamwil; Finance;

Business Development;

Welfare Improving

\begin{abstract}
A B S T R A C T
The growth and development of economic in Indonesia are not only from big cimpanies or multinational, but also the small business, micro business, and middle business have main problems in financial. To solve the problems, Baitul Maal Wat Tamwil (BMT) comes to give the finance to the micro businessmen easily. The aim of this research was to khow the role of finance given by Baitul Maal Wat Tamwil towards the perception of business development and the welfare improving for the members of BMT from micro sector. The samples of the researches were 119 of the members of BMT finance whose jobs were sellers in traditional market in Bantul Regency. The data used for the research were primary data by distributing questionnaires. The data analysis employs Structural Equation Modelling (SEM). The results reveal that the BMT's finance does not has significant influence towards the perception of business development and the welfare improving. However, the business growth has significant influence towards the perception of the wefare improving of the members.
\end{abstract}

(C) 2016 JAI. All rights reserved

\section{PENDAHULUAN}

Seperti telah diketahui bersama, bahwa ekonomi memiliki peranan yang penting untuk menjaga kestabilan kehidupan berbangsa dan bernegara. Tingkat pertumbuhan dan pembangunan suatu negara dapat dilihat dari indikator ekonomi (Suryati, 2012). Pertumbuhan dan perkembangan perekonomian dapat berasal dari para pelaku usaha, baik dari perusahaan besar, multinasional, maupun usaha kecil dan menengah. Meskipun banyak pelaku usaha di Indonesia, tidak semua usaha dapat bertahan pada saat terjadi krisis global. Dalam masa krisis ekonomi yang pernah melanda Indonesia, pengusaha dan pedagang kecil mampu menunjukkan kemampuan untuk bertahan (Sriyatun, 2009). Hal tersebut karena pengusaha dan pedagang kecil tidak terikat dengan utang luar negeri. Saat terjadi krisis global, nilai rupiah melemah sehingga nilai tukar mata uang asing menjadi tinggi yang mengakibatkan naiknya nilai utang ke luar negeri.

Kontribusi usaha mikro, kecil, dan menengah adalah dapat menyerap tenaga kerja (Nurrohmah, 2015). Kemampuan tersebut turut berperan dalam mengurangi pengangguran di Indonesia yang artinya dapat menaikkan pendapatan per kapita masyarakat di Indonesia. Naiknya pendapatan perkapita turut menyumbang pertumbuhan dan perkembangan perekonomian di Indonesia.

Namun disisi lain kemampuan pengusaha kecil mempunyai berbagai kelemahan terutama dalam tiga hal yaitu manajemen, skill dan finansial (Srivatun, 2009). Meskipun berperan besar pada perekonomian, usaha kecil, mikro, dan menengah di Indonesia jarang mendapat akses dari lembaga keuangan khususnya pada tingkat usaha mikro (Saputra, 2015). Untuk mengatasi kelemahan tersebut dibutuhkan pihak lain yang dapat membantu. Lembaga keuangan mikro syariah dinilai dapat membantu mengatasi salah satu permasalahan tersebut, yaitu permasalahan finansial. Salah satu lembaga yang berupaya mengatasi masalah tersebut adalah Baitul Maal Wat Tamwil (BMT).

BMT merupakan salah satu lembaga keuangan syariah yang ada di Indonesia yang beroperasi berdasarkan prinsip-prinsip syariah dengan dua fungsi utama yaitu baitul maal dan baitul tamwil (Soemitra, 2009). BMT menjadi salah satu lembaga 
keungan syariah yang melindungi masyarakat menengah kebawah dari sistem bunga yang diterapkan oleh lembaga konvensional serta dari rentenir yang mematok bunga tinggi pada nasabahnya. BMT berbeda dengan lembaga keuangan lain yang memberikan pembiayaan konsumtif sehingga perekonomian masyarakat cenderung konsumtif. BMT cenderung memberikan pembiayaan berupa modal kerja kepada masyarakat yang mempunyai usaha mikro agar masyarakat di dorong untuk lebih kreatif dan produktif. Sehingga dapat mengangkat perekonomian masayarakat menengah kebawah.

Berdasar data empiris, jumlah usaha mikro di Bantul semakin banyak dari tahun ke tahun (www.pasar.bantulkab.go.id). Hal tersebut dapat dikatakan sejalan dengan peningkatan jumlah BMT yang ada di Bantul. Peningkatan jumlah BMT tentunya akan diikuti dengan meningkatnya jumlah pembiayaan yang diberikan. Namun demikian masih kerap ditemukan beberapa kendala finansial oleh usaha mikro, seperti adanya pembiayaan yang tinggi.

Di Bantul, perkembangan pasar tradisional sangat pesat. Terdapat 31 pasar tradisional dengan sekitar 12.311 pedagang pasar tradisional tercatat (www.pasar.bantulkab.go.id). Bahkan pemerintah daerah Kabupaten Bantul sangat mendorong perkembangan pasar tradisional. Hal tersebut menjadi peluang bagi pengusaha mikro untuk mengembangkan usaha. Dengan bertambah jumlah pelaku usaha mikro akan menjadi peluang yang bagus untuk BMT dalam menyalurkan pembiayaan. Untuk mengetahui apakah pembiayaan BMT berpengaruh terhadap perkembangan usaha anggota, maka perlu dilakukan beberapa penelitian. Motivasi penelitian ini adalah untuk menemukan bukti empiris bahwa memang benar pembiayaan yang dikucurkan BMT memiliki dampak positif bagi masyarakat, terutama pelaku usaha mikro yang mengalami permasalahan pendanaan (sejalan dengan tujuan BMT untuk memberdayakan ummat).

Hasil penelitian Suryati (2012), menunjukkan bahwa pembiayaan mudharabah berpengaruh signifikan terhadap perkembangan usaha nasabah. Azizuddin (2014), mengungkapkan bahwa pembiayaan BMT berpengaruh signifikan terhadap perkembangan usaha pedagang pasar tradisional. Penelitian Wijayanto (2003) menunjukkan bahwa perkembangan usaha kecil ditinjau dari penjualan sebelum dan sesudah mendapatkan kredit tidak ada perbedaannya. Penelitian Prastiani (2012), menyebutkan bahwa pembiayaan syariah berpengaruh terhadap peningkatan kesejahteraan.

Berdasarkan latar belakang di atas, maka permasalahan yang dihadapai dapat dirumuskan sebagai berikut: 1) Apakah pembiayaan BMT berpengaruh positif signifikan terhadap persepsi perkembangan usaha anggota; 2) Apakah pembiayaan BMT berpengaruh positif signifikan terhadap persepsi peningkatan kesejahteraan anggota; 3) Apakah perkembangan usaha berpengaruh positif signifikan terhadap persepsi peningkatan kesejahteraan anggota.

Sesuai dengan rumusan masalah diatas maka penelitian ini mempunyai tujuan sebagai berikut: 1) Menguji dan menemukan bukti empiris apakah pembiayaan BMT berpengaruh positif signifikan terhadap persepsi perkembangan usaha anggota; 2) Menguji dan menemukan bukti empiris apakah pembiayaan BMT berpengaruh positif signifikan terhadap persepsi peningkatan kesejahteraan anggota; 3) Menguji dan menemukan bukti empiris apakah perkembangan usaha berpengaruh positif signifikan terhadap persepsi peningkatan kesejahteraan anggota.

Batasan dalam penelitian ini adalah hanya menggunakan tiga variabel yaitu pembiayaan BMT, perkembangan usaha dan peningkatan kesejahteraan. Walaupun menggunakan tiga variabel, peneliti memandang bahwa variabel-variabel tersebut sangat mendasar. Variabel pembiayaan BMT merupakan data dengan besaran rupiah dana, namun untuk variabel perkembangan usaha dan peningkatan kesejahteraan adalah berdasar persepsi responden (data primer). Dua variabel tersebut menggunakan data primer karena persepsi dari pelaku usaha mikro memegang peranan yang sangat penting untuk sustainability keberlangsungan kemitraan antara BMT dengan anggotanya.

\section{TINJAUAN LITERATUR DAN PERUMUSAN HIPOTESIS}

\section{Baitul Maal Wat Tamwil (BMT)}

BMT sebagai lembaga keuangan bertugas menghimpun dana dari masyarakat (anggota BMT) yang mempercayakan dananya disimpan di BMT dan menyalurkan dana kepada masyarakat (anggota BMT) oleh BMT (Soemitra, 2009). Baitul Mal Wat Tamwil (BMT) merupakan lembaga keuangan mikro syariah yang beroperasi berdasarkan prinsipprinsip syariah (Soemitra, 2009). BMT juga sering disebut sebagai Koperasi Syariah (perijinan sebagai koperasi oleh Kemenkop UKM). Fungsi BMT yaitu sebagai baitul mal dan baitut tamwil. Sebagai baitul mal, BMT menerima titipan dana zakat, infak dan sedekah serta mengoptimalkan distribusinya sesuai peraturan dan amanahnya. Sedangkan sebagai baitut tamwil, BMT melakukan kegiatan pengembangan usaha-usaha produktif dan investasi dalam mening- 
katkan kualitas ekonomi pengusaha mikro dan kecil dengan kegiatan menabung dan menunjang pembiayaan.

Salah satu kendala pelaku usaha mikro adalah modal finansial yang kurang. Padahal modal finansial dapat dikatakan sebagai salah satu modal utama dalam membentuk suatu usaha. Kendala tersebut dapat teratasi dengan adanya lembaga keuangan mikro baik konvensional maupun syariah yang menyalurkan dananya kepada para pelaku usaha mikro. Sebagaimana lembaga keuangan mikro konvensional, lembaga keuangan mikro syariah BMT menyalurkan pembiayaannya kepada para pelaku usaha mikro sebagai anggotanya dengan mudah dan cepat.

Pembiayaan BMT kepada anggotanya diberikan dengan syarat yang mudah. Selain itu, BMT terjun langsung ke lokasi para pelaku usaha mikro untuk menyalurkan pembiayaanya sehingga para pelaku usaha mikro tidak perlu datang ke kantor BMT. Kemudahan tersebut menjadi keunggulan BMT dan umumnya diminati oleh para pelaku usaha mikro. Namun demikian BMT bertanggungjawab terhadap pembinaan anggotanya terutama anggota yang melakukan pembiayaan.

Meningkatnya kesejahteraan masyarakat menunjukkan bahwa pembiayaan yang disalurkan BMT dapat meningkatkan kesejahteraan masyarakat, yang berarti membantu sistem perekonomian di Indonesia terutama dalam pengentasan kemiskinan. Peran BMT dalam meningkatkan kesejahteraan masyarakat menunjukkan bahwa sistem ekonomi dengan prinsip syariah turut berperan dalam mengurangi kemiskinan di Indonesia, melalui peningkatan kesejahteraan masyarakat pelaku usaha mikro.

\section{Pembiayaan BMT}

Penyaluran pembiayaan BMT akan menambah modal finansial bagi para pelaku usaha mikro. Pembiayaan tersebut dapat digunakan sebagai modal awal maupun sebagai modal tambahan untuk mengembangkan usaha, baik menambah barang dagangan atau memperluas dan menambah tempat usaha. Pembiayaan yaitu pendanaan yang diberikan oleh suatu pihak kepada pihak lain untuk mendukung investasi yang telah direncanakan, baik dilakukan sendiri maupun lembaga (Muhammad, 2005). Salah satu bagian terpenting dari aktivitas BMT adalah kemampuan dalam penyaluran dana karena kapasitas penyaluran dana sangat berpengaruh terhadap kinerja lembaga.

Pembiayaan yang diberikan BMT meliputi pembiayaan kerjasama usaha yaitu mudharabah dan musyarakah. Mudharabah merupakan akad kerja- sama usaha antara pihak pemilik dana (shahibul maa) dengan pihak pengelola dana (mudharib) dimana keuntungan dibagi sesuai dengan nisbah yang telah disepakati sebelumnya, sedangkan kerugian finansial ditanggung pemilik dana (PSAK 105). Menurut PSAK 106 musyarakah sebagai akad kerjasama antara dua pihak atau lebih untuk suatu usaha tertentu, dimana masing-masing pihak memberikan kontribusi dana dengan ketentuan bahwa keuntungan dibagi berdasarkan kesepakatan sedangkan kerugian berdasarkan kontribusi dana.

Selain akad kerjasama, terdapat akad jual beli yang disebut dengan murabahah, yaitu akad jual beli barang dengan harga jual sebesar biaya perolehan ditambah keuntungan yang disepakati dan penjual harus mengungkapkan biaya perolehan barang tersebut kepada pembeli (PSAK 102). Ada pula akad sewa menyewa yang dibagi menjadi dua macam yaitu ijarah dan ijarah muntahiya bit tamlik. Ijarah merupakan akad pemindahan hak guna atas barang dan jasa melalui pembayaran upah tanpa diikuti dengan pemindahan kepemilikan barang. Sedangkan Ijarah Muntahiya Bit Tamlik adalah akad pemindahan hak guna atas barang dan jasa melalui pembayaran upah dengan diikuti pemindahan kepemilikan. Jadi setelah masa sewa berakhir, pihak yang menyewa mengadakan akad kembali dengan pihak yang menyewakan untuk melakukan pemindahan hak kepemilikan.

Pembiayaan lain yang diberikan BMT kepada anggotanya adalah qardh, yaitu pembiayaan tanpa dikenakan biaya (hanya wajib membayar sebesar pokok pembiayaan). Pada BMT, qardh digunakan untuk pendampingan usaha dan membantu biaya pemasaran.

\section{Teori Persepsi}

Manusia dapat dikatakan merupakan makhluk invidu sekaligus makhluk sosial. Perbedaan persepsi setiap individu adalah karena manusia (sebagai makhluk individu) melihat suatu hal berbeda-beda sesuai dengan tingkat pemahaman dan tingkat pengetahuan yang dimiliki. Menurut Kamus Besar Bahasa Indonesia Depdiknas RI, persepsi didefinisikan sebagai tanggapan atau penerimaan langsung dari sesuatu atau merupakan proses seseorang mengetahui beberapa hal melalui panca indranya (Depdiknas RI, 2005). Menurut McLaughin dalam Suharini (2008), persepsi merupakan suatu proses yang timbul akibat adanya suatu aktivitas merasakan atau penyebab dari keadaan suatu emosi.

Menurut James dalam Farandy (2013), terdapat tiga bentuk persepsi antara lain pesepsi masa lampau 
disebut dengan persepsi ingatan (tanggapan), persepsi masa sekarang disebut dengan persepsi tanggapan imajinasi, dan persepsi masa mendatang disebut sebagai tanggapan antisipatif. Dari penjelasan tersebut dapat dikatakan bahwa persepsi merupakan tanggapan terhadap suatu hal yang terjadi dimasa lalu, dirasakan pada masa sekarang, dan diharapkan terjadi dimasa depan yang terbentuk dari pemahaman dan pengetahuan setiap individu.

\section{Perkembangan Usaha}

Perkembangan usaha adalah suatu bentuk usaha kepada usaha tersebut agar dapat berkembang menjadi lebih baik lagi dan mencapai pada satu titik atau puncak menuju kesuksesan (Nurrohmah, 2015). Indikator perkembangan usaha dapat dilihat dari jumlah pendapatan, laba, nilai penjualan, pelanggan, barang terjual dan perluasan usaha selama jangka waktu tertentu. Pendapatan adalah pengahasilan yang diterima oleh seseorang dari usaha atau kegiatan yang dilakukan dalam jangka waktu tertentu yang dapat berupa barang dan jasa (Fitriyaningsih, 2012). Besarnya pendapatan dapat digunakan sebagai indikator keberhasilan suatu usaha. Apabila pendapatan usaha tersebut meningkat yang diikuti dengan meningkatnya keuntungan dan jumlah pelanggan maka dapat dikatakan bahwa usaha tersebut mengalami perkembangan. Selain itu, bertambahnya tenaga kerja menunjukkan bahwa permintaan pelanggan terhadap barang yang dijual adalah tinggi, sehingga membutuhkan tambahan tenaga kerja untuk memenuhi keinginan pelanggan.

\section{Peningkatan Kesejahteraan}

Kesejahteraan merupakan kondisi dimana masyarakat terpenuhi standar kebutuhan fisik minimum mereka, termasuk kebutuhan psikis dan sosial, sehingga masyakarat dapat merasa baik dan aman serta mampu menjalankan fungsi sosial (Putri, 2014). Melalui pembiayaan yang diberikan, anggota dapat mengembangkan usahanya. Dari usaha yang berkembang akan meningkatkan pendapatan anggota. Apabila pendapatan usaha anggota meningkat maka kesejahteraan anggota akan meningkat.

Indikator kesejahteraan anggota dilihat dari kemampuan anggota untuk memenuhi kebutuhan sehari-hari seperti kebutuhan pokok, kebutuhan tambahan, kebutuhan pendidikan, kebutuhan kesehatan, kebutuhan sosial, kebutuhan spiritual, dan kebutuhan investasi. Apabila indikator tersebut terpenuhi maka anggota dapat dikatakan sejahtera.

\section{Pengaruh Pembiayaan BMT Terhadap Persepsi Anggota BMT tentang Perkembangan Usaha}

Usaha untuk mengatasi kekurangan modal pelaku usaha mikro dan kecil adalah dengan melakukan pembiayaan BMT. Pembiayaan dilakukan dalam rangka untuk meningkatkan perkembangan usaha mikro dan kecil. Perkembangan usaha diukur dengan indikator meningkatnya jumlah pendapatan, laba, barang yang dijual, dan lainnya selama jangka waktu tertentu. Pembiayaan BMT diharapkan dapat menjadi solusi terhadap permasalahan modal para pelaku usaha mikro dan kecil dan dapat menjadi sumber tambahan modal. Sehingga semakin tinggi jumlah pembiayaan yang diberikan maka persepsi perkembangan usaha akan semakin meningkat.

Berdasarkan hasil penelitian Ananda (2011), pemberian kredit berpengaruh terhadap perkembangan usaha mikro dan kecil. Demikian pula Azizuddin (2014) yang menyatakan bahwa pembiayaan BMT berpengaruh signifikan terhadap perkembangan usaha pasar tradisional. Penelitian Rosida (2014), menyatakan bahwa pembiayaan $m u-$ dharabah berpengaruh terhadap perkembangan usaha. Sedangkan Wijayanto (2003), menemukan bahwa pembiayaan yang diberikan BMT tidak mempengaruhi perkembangan usaha. Dari uraian di atas, maka hipotesis penelitian ini adalah:

$\mathrm{H}_{1}$ : Pembiayaan BMT berpengaruh positif signifikan terhadap persepsi anggota BMT tentang perkembangan usahanya.

\section{Pengaruh Pembiayaan BMT Terhadap Persepsi Anggota BMT tentang Peningkatan Kesejahteraan}

Peningkatan kesejahteraan merupakan variabel laten, yaitu variabel yang tidak dapat diukur secara langsung. Peningkatan kesejahteraan diukur dengan dimensi-dimensi tertentu, yaitu kemampuan untuk memenuhi kebutuhan pokok, tambahan, dan lainnya. Sedangkan perkembangan usaha diukur dari pendaptan, laba, penjualan, dan lainnya selama jangka waktu tertentu. Berdasarkan uraian tersebut maka semakin berkembangnya usaha maka penghasilan yang dihasilkan juga naik sehingga kesejahteraan anggota akan meningkat.

Hasil penelitian Prastiani (2012), menyatakan bahwa pemberian pembiayaan syariah berpengaruh terhadap peningkatan kesejahteraan. Ardista (2012), menyatakan bahwa Produk pembiayaan BMT berpengaruh positif terhadap kesejahteraan masyarakat. 
Dari uraian diatas, maka hipotesis penelitian ini adalah:

$\mathrm{H}_{2}$ : Pembiayaan BMT berpengaruh posistif signifikan terhadap persepsi anggota BMT tentang peningkatan kesejahteraannya.

\section{Pengaruh Persepsi Anggota BMT tentang Perkembangan Usaha Terhadap Peningkatan Kesejahteraan}

Pendapatan anggota dapat mengalami peningkatan apabila terjadi perkembangan usaha. Pembiayaan BMT kepada anggota sebagai tambahan modal dapat mengakibatkan perkembangan usaha dan meningkatkan kesejahteraan. Peningkatan kesejahteraan anggota dapat diukur melalui kemampuan untuk memenuhi kebutuhan pokok dan kebutuhan tambahan sehari-hari, sehingga apabila perkembangan usaha meningkat maka persepsi peningkatan kesejahteraan akan meningkat.

Hasil Penelitian Supriyanto (2006) menunjukkan bahwa pengembangan usaha bepengaruh terhadap upaya peningkatan kesejahteraan masyarakat. Hasil serupa juga dikemukakan oleh Prastiani (2012), bahwa pembiayaan syariah berpengaruh terhadap peningkatan kesejahteraan. Dari uraian diatas maka hipotesis dalam penelitian ini adalah:

$\mathrm{H}_{3}$ : Persepsi anggota BMT tentang perkembangan usahanya berpengaruh positif signifikan terhadap peningkatan kesejahteraannya.

\section{METODE PENELITIAN}

\section{Populasi dan Sampel}

Penelitian ini dilakukan dengan metode survey dengan populasinya adalah pedagang di pasar-pasar tradisional di Bantul yang mendapatkan pembiayaan dari BMT yang beroperasi di Bantul. Teknik pengambilan sampel yang digunakan adalah purposive sampling: Purposive samping adalah teknik pengambilan sampel dengan pertimbangan tertentu (Sugiyono, 2014). Pada penelitian ini hal-hal yang menjadi pertimbangan dalam pengambilan sampel adalah: 1) anggota BMT yang sedang dalam periode akad pembiayaan dan masih punya saldo pembiayaan minimal Rp.500.000; 2) anggota BMT merupakan pedagang pasar tradisional di Bantul; dan 3) menjadi anggota dari BMT yang beroperasi di Bantul. Metode pengumpulan data yang digunakan dalam penelitian ini adalah menggunakan kuesioner yang dipandu oleh peneliti (termasuk wawancara), sehingga diupayakan pedagang di pasar tersebut tidak merasa direpotkan dan pengisian data dapat lebih akurat. Kuesioner melalui tahapan pilot test.

\section{Definisi Operasional dan Pengukuran Variabel}

\section{Pembiayaan}

Pembiayaan merupakan pemberian dana oleh pihak yang kelebihan dana kepada pihak yang kekurangan dana (Muhammad, 2005). Variabel pembiayaan (pada analisis ini disingkat menjadi PB) dalam penelitian ini tidak dibatasi pada pembiayaan tertentu saja, namun semua akad pembiayaan. Asumsinya adalah setiap ada pembiayaan dari BMT maka BMT sekaligus telah bertanggungjawab melakukan pembinaan sesuai besaran dana yang disalurkan. Sedangkan anggota BMT bertanggungjawab terhadap besaran rupiah yang digunakan. Variabel pembiayaan BMT dalam penelitian ini diukur dari besar rupiah jumlah pembiayaan yang diberikan secara umum tanpa memandang bentuk akadnya (mudharabah, murabahah, atau lainnya).

\section{Persepsi Perkembangan Usaha}

Persepsi anggota BMT tentang perkembangan usahanya adalah kondisi dimana masyarakat (anggota BMT tersebut) merasa bahwa usahanya semakin berkembang menjadi lebih baik lagi dibanding sebelumnya sehingga menuju kearah puncak kesuksesan. Variabel tersebut selanjutnya dalam analisis ini disebut variabel persepsi perkembangan usaha (disingkat menjadi PU). Variabel persepsi perkembangan usaha terdiri dari 6 dimensi yaitu peningkatan jumlah pendapatan, laba, nilai penjualan, pelanggan, barang terjual dan perluasan usaha selama jangka waktu tertentu. Variabel ini diukur menggunakan skala likert melalui kuesioner yang disebarkan.

\section{Persepsi Peningkatan Kesejahteraan}

Persepsi anggota BMT tentang peningkatan kesejahteraannya adalah kondisi dimana masyarakat (anggota BMT tersebut) merasa standar kebutuhan fisik minumum mereka telah terpenuhi dan mengalami peningkatan termasuk kebutuhan psikis dan sosial, sehingga merasa lebih baik dan aman serta mampu menjalankan fungsi individu dan sosialnya menjadi lebih baik lagi dari sebelumnya. Variabel tersebut selanjutnya dalam analisis ini disebut variabel persepsi peningkatan kesejahteraan (disingkat menjadi PK). Variabel persepsi peningkatan kesejahteraan terdiri dari 7 dimensi yaitu pemenuhan kebutuhan pokok, kebutuhan tambahan, kebutuhan 
pendidikan, kebutuhan kesehatan, kebutuhan sosial, kebutuhan spiritual (karena umumnya anggota BMT adalah muslim maka menjadi kebutuhan ibadah yang terbagi lagi menjadi dimensi wajib yaitu zakat dan dimensi sunah yaitu infak/sedekah), dan kebutuhan investasi/menabung (total menjadi 8 dimensi). Variabel ini diukur menggunakan skala likert melalui kuesioner yang disebarkan.

\section{Teknik dan Metode Analisis Data}

Metoda analisis data dalam penelitian ini menggunakan struktural equation model (SEM). Pada dasarnya SEM adalah merupakan kombinasi dari multiple regression dengan factor analysis dan path analysis secara simultan dan tetap efisien. SEM disebut sebagai generasi kedua dari analisis multivariate. Teknik analisis SEM dalam penelitian ini dibantu dengan menggunakan software IBM SPSS AMOS versi 22.0 (Purnamasari dan Darma, 2011).

Pengujian dilakukan terhadap hubunganhubungan antara variabel yang ada pada model, baik itu antar indikator dengan konstruknya ataupun hubungan antar konstruk. Teknik analisis data menggunakan tahapan pemodelan dan analisis persamaan struktural dibagi menjadi 7 langkah yaitu, 1) pengembangan model secara teoritis, 2) menyusun diagram jalur, 3) mengubah diagram jalur menjadi persamaan struktural, 4) memilih matrik input untuk analisis data, 5) menilai identifikasi model struktural, 6) mengevaluasi kriteria goodness of fit, 7) interpretasi data dan modifikasi model. Model dan Persamaan dalam penelitian ini ditampilkan pada Gambar 1.

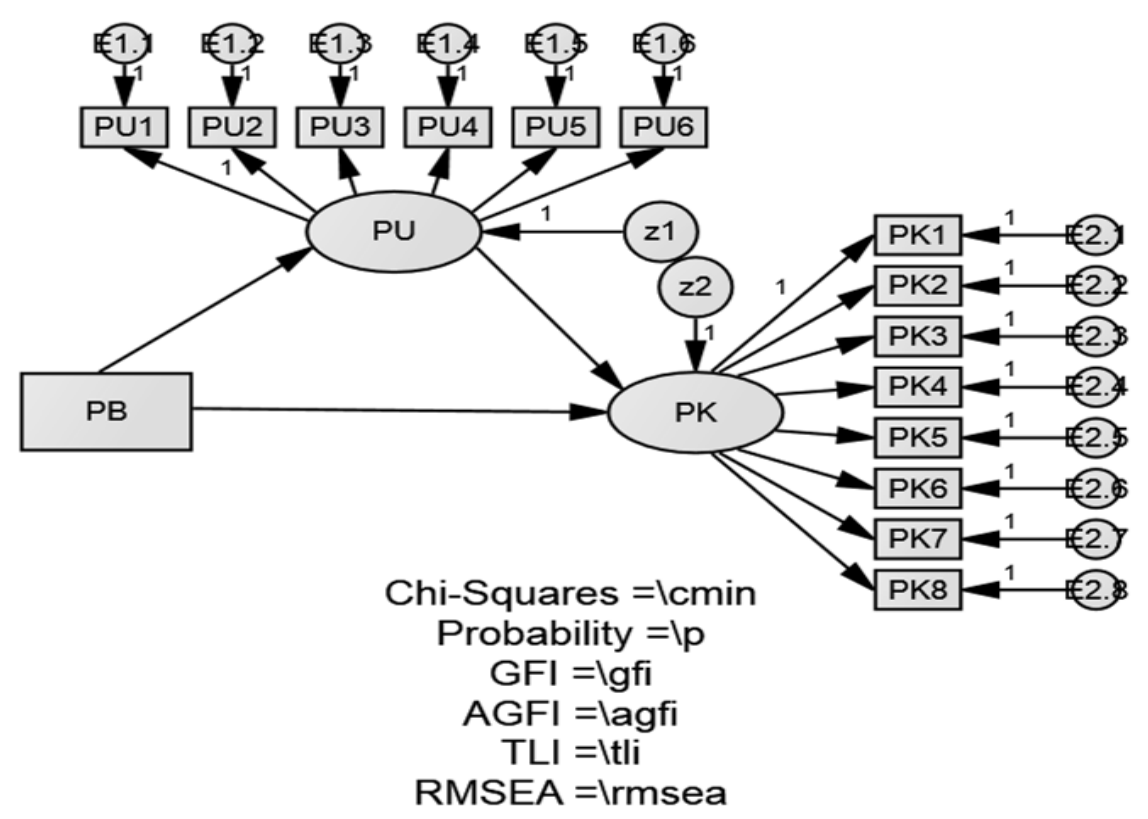

Gambar 1. Model Persamaan Struktural

Persamaan model struktural pada penelitian ini adalah:

$\mathrm{PU}=\gamma 1 \mathrm{~PB}+\zeta$ dan $\mathrm{PK}=\gamma 1 \mathrm{~PB}+\beta 2 \mathrm{PU}+\zeta$.

Persamaan model pengukuran pada penelitian ini adalah:

$\mathrm{PU} 1=\lambda 11 \mathrm{PU}+\varepsilon 1, \mathrm{PU} 2=\lambda 12 \mathrm{PU}+\varepsilon 2, \mathrm{PU} 3=\lambda 13 \mathrm{PU}+\varepsilon 3, \mathrm{PU} 4=\lambda 14 \mathrm{PU}+\varepsilon 4, \mathrm{PU} 5=\lambda 15 \mathrm{PU}+\varepsilon 5, \mathrm{PU} 6$

$=\lambda 16 \mathrm{PU}+\varepsilon 6$

$\mathrm{PK} 1=\lambda 21 \mathrm{PK}+\varepsilon 1, \mathrm{PK} 2=\lambda 22 \mathrm{PK}+\varepsilon 2, \mathrm{PK} 3=\lambda 23 \mathrm{PK}+\varepsilon 3, \mathrm{PK} 4=\lambda 24 \mathrm{PK}+\varepsilon 4, \mathrm{PK} 5=\lambda 25 \mathrm{PK}+\varepsilon 5, \mathrm{PK} 6$

$=\lambda 26 \mathrm{PK}+\varepsilon 6, \mathrm{PK} 7=\lambda 27 \mathrm{PK}+\varepsilon 7, \mathrm{PK} 8=\lambda 28 \mathrm{PK}+\varepsilon 8$.

Keterangan :

$\mathrm{PB}=$ Pembiayaan

$\mathrm{PU}=$ Perkembangan Usaha

PK = Peningkatan Kesejahteraan 


\section{HASIL DAN PEMBAHASAN}

\section{Gambaran Umum Obyek Penelitian}

Peneliti mencukupkan survey pada 7 pasar saja dari 31 pasar tradisional (besar dan kecil) yang ada di Kabupaten Bantul, karena keterbatasan waktu. Waktu survey adalah November sampai Desember 2015. Penyebaran kuesioner kepada 150 responden yang menjadi sampel dianggap dapat mewakili anggota BMT yang berada di pasar tradisional di Bantul. Jika ada seorang pedagang pasar menjadi anggota di lebih dari satu BMT, maka untuk memudahkan adalah dicatat pada yang lebih aktif berinteraksi dengan BMT. Dari 150 kuesioner yang disebarkan, jumlah kuesioner yang kembali dan dapat diolah sebanyak 119 atau $79 \%$.

\section{Tabel 1. Jumlah Responden Berdasarkan BMT}

\begin{tabular}{clcc}
\hline No & Nama BMT & Jumlah & Persentase \\
\hline 1 & Tamziz & 26 & $20 \%$ \\
2 & Bina Ihsanul Fikri & 19 & $14 \%$ \\
3 & Mitra Lohjinawi & 28 & $21 \%$ \\
4 & Artha Amanah & 6 & $5 \%$ \\
5 & Artha Barokah & 1 & $1 \%$ \\
6 & UMY & 1 & $1 \%$ \\
7 & Dana Insani & 17 & $11 \%$ \\
8 & Multazam & 6 & $6 \%$ \\
9 & Mitrama & 6 & $5 \%$ \\
10 & Bina Ummah & 6 & $5 \%$ \\
11 & Insan Sadar Usaha & 2 & $1 \%$ \\
\hline & Total & $\mathbf{1 1 9}$ & $\mathbf{1 0 0 \%}$ \\
\hline
\end{tabular}

Tabel 2. Responden Berdasarkan Lokasi Usaha

\begin{tabular}{clcc}
\hline No & Lokasi Usaha & Jumlah & Persentase \\
\hline 1 & Pasar Bantul & 47 & $39 \%$ \\
2 & Pasar Niten & 28 & $24 \%$ \\
3 & Pasar Barongan & 15 & $13 \%$ \\
4 & Pasar Imogiri & 6 & $5 \%$ \\
5 & Pasar Kepek & 6 & $5 \%$ \\
6 & Pasar Pijenan & 11 & $9 \%$ \\
7 & Pasar Jodog & 6 & $5 \%$ \\
\hline & Total & $\mathbf{1 1 9}$ & $\mathbf{1 0 0 \%}$ \\
\hline
\end{tabular}

Tabel 3. Data Jenis Usaha Responden

\begin{tabular}{clcc}
\hline No & Usaha & Jumlah & Persentase \\
\hline 1 & Sembako & 37 & $33 \%$ \\
2 & Sayuran & 28 & $25 \%$ \\
3 & Buah & 8 & $7 \%$ \\
4 & Bahan Makanan & 4 & $4 \%$ \\
5 & Pakaian & 17 & $4 \%$ \\
6 & Makanan & 16 & $15 \%$ \\
7 & Tas dan Sepatu & 1 & $1 \%$ \\
\hline & Total & $\mathbf{1 1 9}$ & $\mathbf{1 0 0 \%}$ \\
\hline
\end{tabular}

\section{Analisis Data dan Uji Hipotesis}

Sebelum analisis persamaan struktural dilakukan, terlebih dahulu dilakukan confirmatory factor analysis (CFA) untuk masing-masing konstruk (variabel laten) pada PU dan PK. Hal tersebut dilakukan untuk mengetahui apakah masing-masing indikator memang efisien untuk mengukur konstruknya. Dalam pengujian validitas dan reliabilitas indikator variabel konstruk, terdapat beberapa indikator yang tidak valid lalu dihilangkan.
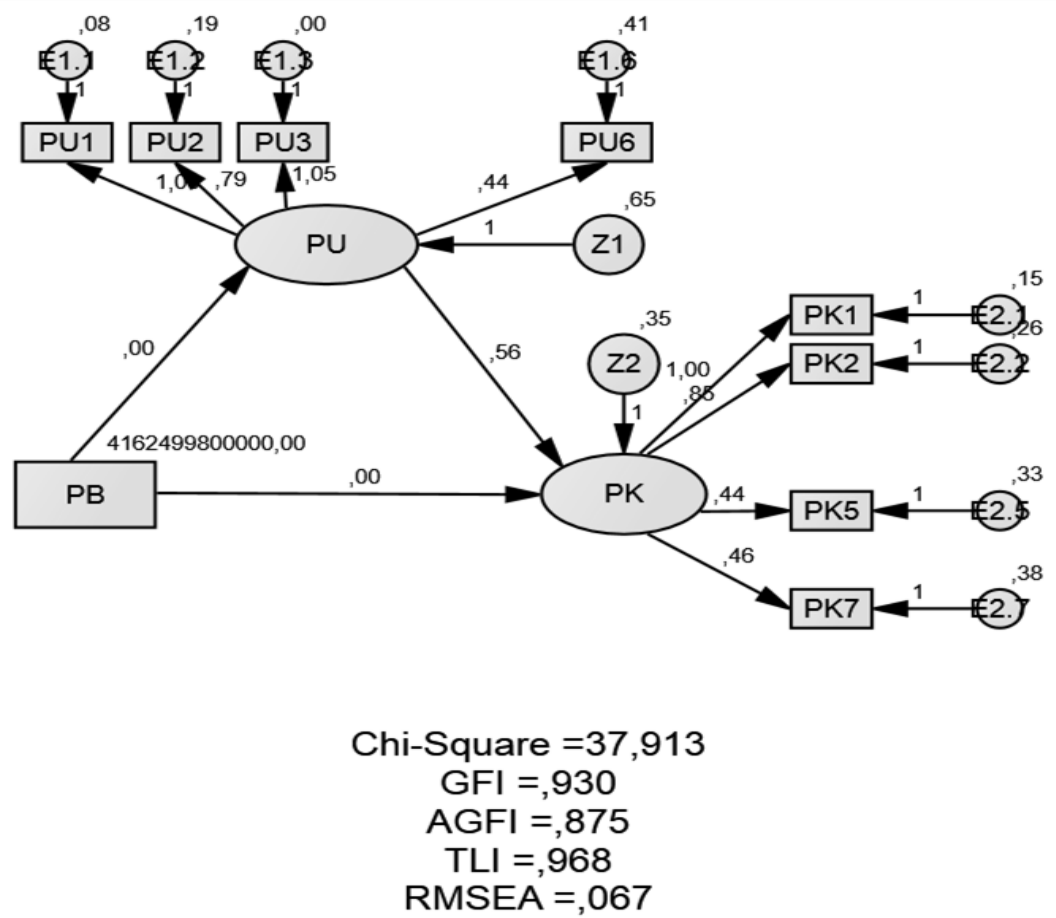

Gambar 2. Pengujian Model Menyeluruh 
Dilakukan pula analisis terhadap normalitas data dan deteksi data outlier serta asumsi-asumsi yang dibutuhkan. Pengujian normalitas meliputi normalitas univariat maupun normalitas multivariat. Setelah dilakukan first order confirmatory factor analysis lalu dilakukan structural equation modeling secara menyeluruh. Dalam setiap pengujian, dilihat pula goodness of fit dari model dengan ukuran yang dipilih: $X^{\prime \prime}$ (Chi-square) dengan probabilitasnya, GFI, AGFI, TLI, dan RMSEA. Setelah tahapan-tahapan di atas telah dilalui, maka dihasilkan model sebagaimana yang ditunjukkan pada Gambar 2.

Secara multivariate pada table Assesment of Normality, nilai c.r. kurtosis 2,510 < 2,58 dapat disimpulkan data telah terdistribusi normal (lihat Tabel 4). Berdasarkan tabel kriteria goodness of fit, dapat dilihat bahwa pengujian indikator goodness of fit secara keseluruhan telah terpenuhi dengan baik (lihat Tabel 5). Sehingga model dalam penelitian ini dapat dikatakan kategori model fit. Sedangkan untuk evaluasi nilai parameter dapat disimak pada Tabel 6 .

Nilai signifikansi dapat dilihat dari tabel $r e g-$ ression weights pada Tabel 6 yang mana nilai probabilitas masing-masing menunjukkan sangat signifikan dengan $\mathrm{P}^{* * *}(0,001)$. Kriteria signifikansi $\mathrm{P}$ adalah $<0,05$. Pada Tabel 6 ditunjukkan hubungan PB terhadap PU >0,05 yaitu 0,187, dan PB terhadap PK $>0,05$ yaitu 0,512 sehingga tidak signifikan.

Tabel 4. Assesment of Normality

\begin{tabular}{lrrrrrr}
\hline Variable & min & max & skew & c.r. & kurtosis & c.r. \\
\hline PB & 500000 & 10000000 & 1,503 & 6,492 & 2,342 & 5,059 \\
PK7 & 2 & 5 & $-0,873$ & $-3,774$ & 0,514 & 1,111 \\
PK5 & 2 & 4 & $-1,200$ & $-5,185$ & 0,227 & 0,491 \\
PK2 & 2 & 5 & $-0,498$ & $-2,152$ & $-0,713$ & $-1,539$ \\
PK1 & 2 & 5 & $-0,885$ & $-3,823$ & 0,423 & 0,913 \\
PU6 & 2 & 5 & 0,187 & 0,807 & $-0,630$ & $-1,361$ \\
PU3 & 2 & 5 & $-0,052$ & $-0,224$ & $-0,635$ & $-1,371$ \\
PU2 & 2 & 5 & 0,336 & 1,450 & $-0,135$ & $-0,291$ \\
PU1 & 2 & 5 & $-0,160$ & $-0,693$ & $-0,591$ & $-1,277$ \\
Multivariate & & & & & 6,675 & 2,510 \\
\hline
\end{tabular}

Tabel 5. Kriteria Goodness of Fit

\begin{tabular}{lccc}
\hline Goodness of Fit Index & Cutt-Off & Hasil Pengujian & Keterangan \\
\hline Chi-Squares & Diharapkan kecil & 37,913 & \\
Probability & $>0,5$ & 0,047 & Marginal \\
GFI & $>0,9$ & 0,930 & Tinggi \\
AGFI & $>0,9$ & 0,875 & Marginal \\
TLI & $>0,9$ & 0,968 & Tinggi \\
RMSEA & $0,05-0,08$ & 0,067 & Tinggi \\
\hline
\end{tabular}

Tabel 6. Regression Weights Full Model

\begin{tabular}{|c|c|c|c|c|c|c|c|}
\hline & & & Estimate & S.E. & C.R. & $\mathbf{P}$ & Label \\
\hline PU & $<-$ & PB & 0,000 & 0,000 & 1,320 & 0,187 & par_1 \\
\hline PK & $<-$ & PU & 0,565 & 0,087 & 6,522 & *** * & par_2 \\
\hline PK & $<-$ & PB & 0,000 & 0,000 & 0,656 & 0,512 & par_3 \\
\hline PU1 & $<-$ & PU & 1,000 & & & & \\
\hline PU2 & $<-$ & $\mathrm{PU}$ & 0,768 & 0,058 & 13,186 & *** & par_4 \\
\hline PU3 & $<-$ & $\mathrm{PU}$ & 1,055 & 0,042 & 24,870 & *** & par_5 \\
\hline PU6 & $<-$ & $\mathrm{PU}$ & 0,411 & 0,078 & 5,258 & *** & par_6 \\
\hline PK1 & $<-$ & PK & 1,000 & & & & \\
\hline PK2 & $<-$ & PK & 0,828 & 0,097 & 8,517 & *** & par_7 \\
\hline PK5 & $<-$ & PK & 0,411 & 0,086 & 4,766 & *** & par_8 \\
\hline PK7 & $<-$ & PK & 0,458 & 0,093 & 4,918 & *** & par_9 \\
\hline
\end{tabular}


Tabel 7. Hubungan Antar Variabel

\begin{tabular}{lccc}
\hline Pengaruh & Estimasi & Signifikansi & Keterangan \\
\hline Pembiayaan $\rightarrow$ Perkembangan Usaha & 0,125 & 0,224 & Hipotesis Ditolak \\
Pembiayaan $\rightarrow$ Peningkatan Kesejahteraan & 0,057 & 0,529 & Hipotesis Ditolak \\
Perkembangan Usaha $\rightarrow$ Peningkatan Kesejahteraan & 0,599 & 0,001 & Hipotesis Diterima \\
\hline
\end{tabular}

\section{Diskusi}

Hasil pengujian H1 pada penelitian ini menunjukkan bahwa pembiayaan BMT tidak berpengaruh signifikan terhadap persepsi anggota BMT tentang perkembangan usahanya. Hal tersebut berdasarkan hasil perhitungan yang ditunjukkan oleh regression weights pada nilai probabilitas signifikansi sebesar 0,187 yang lebih besar dari 0,05 walaupun arah hipotesis sudah benar positif (yang ditunjukkan dari tabel standardized regression) sebesar 0,125. Oleh sebab itu $\mathrm{H} 1$ ditolak.

Penelitian ini tidak berhasil mendukung penelitian Ananda (2011), demikian pula penelitian Azizuddin (2014) yang menyatakan bahwa pembiayaan BMT berpengaruh signifikan terhadap perkembangan usaha pasar tradisional. Hasil penelitian ini juga tidak sejalan dengan penelitian Rosida (2014) yang menyatakan bahwa pembiayaan mudharabah berpengaruh terhadap perkembangan usaha. Namun hasil penelitian ini sama dengan hasil penelitian Wijayanto (2003) yang menemukan bahwa pembiayaan yang diberikan BMT tidak memengaruhi perkembangan usaha.

Hal tersebut diduga karena kemungkinan perkembangan usaha ditentukan lebih dominan oleh kondisi pasar. Apabila pasar sedang ramai oleh pengunjung maka penjualan mereka akan menjadi naik. Selain kondisi pasar, jumlah pesaing juga menentukan perkembangan usaha pedagang pasar. Semakin banyak pesaing maka semakin sulit untuk mengembangkan usaha mereka. Jadi, meskipun pembiayaan yang diberikan BMT tinggi apabila kondisi pasar sedang tidak baik maka usaha anggota kurang dapat berkembang. Namun jika pasar sedang bagus, maka terasa kemanfaatan pembiayaan tersebut. Andai kata memang demikian penyebabnya (perlu penelitian lanjutan), maka menjadi tugas BMT juga untuk memperjuangkan agar kondisi pasar semakin baik dan BMT juga harus bersifat antisipatif terhadap kondisi ekonomi makro yang berdampak sampai ke pasar-pasar tradisional. BMT juga harus responsif terhadap kebutuhan anggotanya pada kondisi pasar yang sedang tidak bagus (misal dalam pembinaan, kemitraan dengan pihak lain, penentuan nisbah bagi hasil, margin keuntungan, penjadwalan ulang, dll).

Hasil pengujian H2 menunjukkan bahwa pembiayaan BMT mempunyai pengaruh positif namun tidak signifikan terhadap persepsi anggota BMT tentang peningkatan kesejahteraannya. Berdasarkan hasil perhitungan yang ditunjukkan oleh regression weights pada nilai signifikansi sebesar 0,512 yang lebih besar dari 0,05 dan arah hipotesis positif (yang ditunjukkan dari tabel standardized regression) yaitu sebesar 0,057. Oleh sebab itu H2 ditolak.

Penelitian ini tidak berhasil mendukung penelitian Prastiani (2012) yang menyatakan bahwa pembiayaan syariah berpengaruh terhadap peningkatan kesejahteraan. Demikian pula dengan penelitian Ardista (2012) yang menyatakan bahwa Produk pembiayaan BMT berpengaruh positif terhadap kesejahteraan masyarakat. Hal tersebut diduga karena peningkatan kesejahteraan tidak diperhatikan dari besarnya pembiayaan yang diberikan BMT, tetapi pada penghasilan dan perkembangan usaha pedagang. Padahal perkembangan usaha pedagang tersebut dipengaruhi oleh beberapa faktor lain diluar BMT. Bahkan diduga banyak pedagang yang masih menggunakan jasa keuangan konvensional resmi disamping jasa BMT, misal koperasi BUKP (Badan Usaha Kredit Pedesaan) milik Pemda yang ada disetiap kecamatan (yang juga sering turun ke pasar atau rumah penduduk) serta bentuk lembaga keuangan konvensional mikro lainnya. Mereka mungkin merasa peningkatan kesejahteraannya tidak semata-mata karena BMT telah mengucurkan dananya ke mereka.

BMT mungkin bisa bersaing menghadapi rentenir pasar (sering disebut "bank plecit") dengan bunganya yang mencekik, namun akan sulit bersaing dengan lembaga keuangan konvensional mikro yang berani menawarkan bunga relatif rendah. Andaikata memang demikian penyebabnya (perlu penelitian lanjutan), maka menjadi tugas BMT dan berbagai pihak untuk menggiring secara bijak agar mereka lambat laun berubah dari manusia yang hanya rasional saja menjadi insan yang memiliki sentimen keagamaan yang baik. Sehingga transaksi syariah di sektor mikro semakin digemari karena dianggap oleh mereka lebih afdhol, untuk kesejahteraan dunia dan akhirat.

Hasil pengujian H3 menunjukkan bahwa persepsi anggota BMT tentang perkembangan usahanya mempunyai pengaruh positif dan signifikan terhadap peningkatan kesejahteraannya. Berdasarkan hasil perhitungan yang ditunjukkan oleh regression weights pada nilai probabilitas signifikansi sebesar 0,001 
yang lebih kecil dari 0,05 dan arah positif (yang ditunjukkan dari tabel standardized regression) yaitu sebesar 0,599. Oleh sebab itu H3 diterima.

Pengujian ini secara statistik membuktikan bahwa persepsi masyarakat (dalam hal ini anggota BMT) tentang perkembangan usaha yang baik akan menyebabkan baik pula dalam peningkatkan kesejahteraan masyarakat. Penelitian ini mendukung penelitian Supriyanto (2006) dan Prastiani (2012) yang menunjukkan bahwa perkembangan usaha bepengaruh terhadap upaya peningkatan kesejahteraan masyarakat.

\section{SIMPULAN}

Hasil penelitian ini menunjukkan bahwa pembiayaan BMT pada pedagang pasar tradisional yang menjadi anggota BMT di Bantul, tidak berpengaruh signifikan terhadap persepsi pedagang tersebut tentang perkembangan usahanya dan peningkatan kesejahteraannya (walaupun arahnya sudah benar positif). Namun demikian, persepsi pedagang tersebut tentang perkembangan usahanya berpengaruh positif signifikan terhadap persepsi peningkatan kesejahteraannya. Dapat dikatakan bahwa berdasar persepsi para pelaku usaha mikro pedagang di pasar-pasar tradisional kabupaten Bantul sebagai berikut: Secara umum BMT sudah memiliki peran positif terhadap perkembangan usaha dan peningkatan kesejahteraan, namun terlalu kecil atau tidak signifikan. Demikianlah hasil penelitian ini. Hal tersebut menjadi tantangan bagi BMT BMT yang beroperasi di kabupaten Bantul.

Berdasarkan kesimpulan dari hasil penelitian diatas, maka saran dari peneliti untuk penelitian selanjutnya adalah diharapkan dapat menambah variabel penelitian (misal kondisi pasar, tingkat persaingan usaha, maupun variabel lainnya). Mungkin perlu diklasifikasi pula jenis-jenis akad pembiayaannya. Menjadi tugas semua pihak untuk lebih berupaya menyuburkan transaksi keuangan syariah di sektor mikro (Darma dan Rita, 2011; Sofyani et al., 2012; Sofyani dan Setiawan, 2015; Junaidi, 2015; Hasbi dan Hadi; 2016).

Dalam penelitian ini, tidak diklasifikasi jenis pembiayaannya. Selain itu, tingkat pemahaman banyak responden yang cenderung rendah tentang pengisian kuesioner menyebabkan peneliti sering harus membacakan satu persatu pertanyaan dalam kuesioner. Hal tersebut memakan waktu cukup lama sehingga kurang maksimal dalam mendapatkan responden dalam jumlah yang lebih banyak lagi. Disamping itu, pembiayaan oleh BMT dianggap (asumsi) sekaligus sebagai pembinaan, sesuai dengan tujuan BMT secara umum. Padahal tidak setiap BMT memiliki keseragaman dalam model pembinaannya maupun tingkat intensifnya pembinaan. Penelitian selanjutnya sebaiknya menambahkan variabel pembinaan tersebut. Oleh sebab itu, penelitian langsung turun ke bawah (sektor keuangan mikro) sebaiknya lebih sering dilakukan, sebagai salah satu pondasi kekuatan keuangan syariah kelak.

\section{LAMPIRAN}

\section{Instrumen Variabel Perkembangan Usaha}

(1) Pendapatan saya masa sekarang (pada periode pembiayaan BMT) meningkat.

(2) Laba dari usaha saya masa sekarang (pada periode pembiayaan BMT) meningkat.

(3) Nilai penjualan dari usaha saya masa sekarang (pada periode pembiayaan BMT) meningkat.

(4) Jumlah pelanggan saya masa sekarang (pada periode pembiayaan BMT) nampak bertambah.

(5) Jumlah barang yang saya jual masa sekarang (pada periode pembiayaan BMT) tergolong meningkat.

(6) Usaha saya masa sekarang (pada periode pembiayaan BMT) mengalami perluasan atau peningkatan.

\section{Instrumen Variabel Peningkatan Kesejahteraan}

(1) Penghasilan saya meningkat dan semakin cukup untuk memenuhi kebutuhan pokok/sehari-hari.

(2) Penghasilan saya meningkat dan cukup untuk memenuhi kebutuhan tambahan yang diperlukan.

(3) Penghasilan saya meningkat dan lumayan cukup untuk memenuhi kebutuhan pendidikan keluarga saya.

(4) Penghasilan saya meningkat dan dapat dikatakan cukup untuk memenuhi kebutuhan kesehatan keluarga saya.

(5) Penghasilan saya meningkat dan cukup untuk memenuhi kebutuhan sosial kemasyarakatan di lingkungan saya.

(6) Penghasilan saya meningkat dan dapat untuk mengeluarkan zakat, atau zakat saya meningkat.

(7) Penghasilan saya meningkat dan dapat untuk mengeluarkan infaq/sodaqoh, atau infaq/sodaqoh saya meningkat.

(8) Penghasilan saya meningkat dan semakin dapat disisihkan untuk investasi/menabung. 


\section{DAFTAR PUSTAKA}

Ananda, F. 2011. Analisis Perkembangan Usaha Mikro Dan Kecil Setelah Memperoleh Pembiayaan Mudharabah Dari BMT At Taqwa Halmahera Di Kota Semarang. Skripsi, Universitas Diponegoro.

Apriliasari, K. 2015. Pengaruh Lingkungan Kerja Terhadap Kinerja Melalui Kepuasan Kerja Sebagai Variabel Intervening Studi Kasus Pada Kantor Wilayah Bank Bri Yogyakarta. Skripsi, Universitas Muhammadiyah Yogyakarta.

Ardista, N. R. 2012. Peran Produk Pembiayaan Terhadap Kesejahteraan Masyarakat Pada BMT Nurul Barokah Sambi, Boyolali. Skripsi, Universitas Muhammadiyah Surakarta.

Azizuddin, A. 2014. Peran Pembiayaan Baitul Maal Wat Tamwil Terhadap Perkembangan Usaha Pedagang Pasar Tradisional di Provinsi Yogyakarta. Skrpsi, Universitas Muhammadiyah Yogyakarta.

Cunningham, E. 2008. A Practical Guide To Structural Equation Modeling Using Amos. Melbourne: Statsline.

Darma, E. S. dan Rita. 2011. Faktor-Faktor Yang Berpengaruh terhadap Tingkat Pengguliran Dana Bank Syariah. Jurnal Akuntansi dan Investasi, 12 (1), 72-87.

Depdiknas RI. 2005. Kamus Besar Bahasa Indonesia (KBBI). Ed3. Balai Pustaka. Jakarta.

Ernawati, R. 2012. Analisis Akad Pembiayaan Mudharabah Pada Bmt Dalam Meningkatkan Pendapatan Masyarakat (Studi Kasus pada KJKS-BMT Ummat Sejahtera Abadi Rembang). Skripsi, Institut Agama Islam Negeri Walisongo.

Farandy, A. A. Y. 2013. Persepsi Konsumen Belanja Online Di Surabaya Terhadap Situs Belanja Online "Toko Bagus" Di Internet (Studi Deskriptif Persepsi Konsumen Belanja Online Di Surabaya Terhadap Situs Belanja Online Toko Bagus Di Internet). Skripsi, UPN Jawa Timur.

Fitriyaningsih, E. 2012. Pengaruh Besar Modal (Modal Sendiri), Pemberian Kredit, Dan Tingkat Suku Bunga Kredit Terhadap Peningkatan Pendapatan Pedagang Kecil Di Desa Tirtonirmolo Kecamatan Kasihan Bantul. Skripsi, Universitas Negeri Yogyakarta.

Hasbi, S. dan K. Hadi. 2016. Evaluasi Pembiayaan Perumahan Akad Murabahah Versus Kredit
Konvensional Berdasarkan Volatilitas Harga. Jurnal Akuntansi dan Investasi, 17 (1), 22-41.

Junaidi. 2015. Analisis Pengungkapan CSR Perbankan Syariah di Indonesia Berdasarkan Islamic Social Reporting Index. Jurnal Akuntansi dan Investasi, 16 (1), 75-85.

Kara, M. 2013. Konstribusi Pembiayaan Perbankan Syariah Terhadap Pengembangan Usaha Mikro, Kecil, Dan Menengah. Jurnal Ahkam, 13 (2).

Muhammad. 2002. Bank Syariah Analisis Kekuatan, Kelemahan, Peluang dan Ancaman. Yogyakarta: Ekonisia.

Muhammad. 2005. Manajemen Pembiayaan Bank Syariah. Yogyakarta: UPP AMP YKPN.

Murwanti, S. dan M. Sholahuddin. 2013. Peran Keuangan Lembaga Mikro Syariah Untuk Usaha Mikro Di Wonogiri. Proceeding Seminar Nasional Dan Call For Papers Sancall. Hal. 300-309.

Nurrohmah, I. 2015. Analisis Perkembangan Usaha Mikro, Kecil Dan Menengah Sebelum Dan Sesudah Menerima Pembiayaan Musyarakah Pada Koperasi Jasa Keuangan Syariah BMT (Studi Kasus: Bmt Beringharjo Yogyakarta). Skripsi, Universitas Negeri Yogyakarta.

Prastiani, S. C. 2012. Peranan Pembiayaan Syariah Terhadap Peningaktan Kesejahteraan Nasabah. Skripsi, Universitas Pamulang.

Purnamasari, I., dan E. S. Darma. 2015. Pengaruh Implementasi Syariah Governance Terhadap Loyalitas Nasabah. Jurnal Akuntansi dan Investasi, 16 (1), 12-24.

Putri, I. K. K.. 2014. Analisis Pengaruh Pertumbuhan Perbankan Syariah Terhadap Kesejahteraan (Indeks Pembangunan Manusia) di Indonesia Pada Tahun 20102012. Skripsi, Universitas Islam Negeri Sunan Kalijaga.

Rosida, A. 2014. Pengaruh Pembiayaan Murabahah Bmt Artha Amanah Terhadap Perkembangan Usaha Dan Peningkatan Pendapatan Pada Usaha Mikro. Jurnal Pendidikan dan Ekonomi, 8 (1).

Saputra, A. 2015. Pengaruh Penyaluran Pembiayaan BMT Bina Ihsanul Fikri (BIF) terhadap Perkembangan Usaha Pedagang Pasar Tradisional di Kota Yogyakarta. Skripsi, Universitas Muhammadiyah Yogyakarta.

Soemitra, A. 2009. Bank dan Lembaga Keuangan Syariah. Jakarta: Kencana Prenada Media Group.

Sofyani, H., I. Ulum, D. Syam dan S.W. Latifah. 2012. Islamic Social Reporting Index Sebagai Model Pengukuran Kinerja Sosial Perbankan 
Syariah (Studi Komparasi Indonesia dan Malaysia). Jurnal Dinamika Akuntansi, 4 (1), 36-46.

Sofyani, H., dan A. Setiawan. 2015. Perbankan Syariah dan Tanggungjawab Sosial: Sebuah Studi Komparasi Indonesia dan Malaysia dengan Pendekatan Islamic Social Reporting Index Dan Global Reporting Initiative Index. At-Taradhi, 5 (2), 1-7.

Sriyatun. 2009. Analisis Pengaruh Pemberian Pembiayaan Mudharabah Bmt Terhadap Peningkatan Pendapatan Pedagang Kecil Di Kabupaten Sukoharjo. Skripsi, Universitas Muhammadiyah Surakarta.

Sugiyono. 2014. Metode Penelitian Bisnis. Bandung: Alfabeta, Cetakan keempat belas.

Suharini, M. 2008. Persepsi Nasabah terhadap Penerapan Sistem Layanan Produk dan Jasa E-Banking. Jurnal Ilmu Administrasi dan Organisasi, 15 (3).

Supriyanto. 2006. Pemberdayaan Usaha Mikro, Kecil, Dan Menengah (UMKM) Sebagai Salah Satu Upaya Penanggulangan Kemiskinan. Jurnal Ekonomi dan Pendidikan, 3 (1).

Suryati. 2012. Pengaruh Pembiayaan Mudharabah BMT Binamas Terhadap Perkembangan Usaha Dan Pendapatan Nasabah Mudharabah Di Bmt Binamas Purworejo. Skripsi, Universitas Negeri Yogyakarta.

Wijayanto, J. 2003. Analisis Hubungan Kredit BMT Al-Fattah Terhadap Perkembangan Usaha Kecil Di Kecamatan Susukan Salatiga. Skripsi, Universitas Muhammadiyah Surakarta.

www.pasar.bantulkab.go.id 